\title{
ASSESSMENT OF THE DOCUMENTATION INFORMATION SYSTEM FOR PRIMARY HEALTH CARE ACCREDITATION USING SIX SIGMA METHOD IN BEKASI, WEST JAVA
}

\author{
Dia Melisa Rafdi, Dian Ayubi \\ Masters Program in Public Health, Faculty of Public Health, Universitas Indonesia
}

\begin{abstract}
Background: Accreditation is a method used to improve and measure the quality of health service. Documentation information system is a basic accreditation assessment in primary health care. However, it has some barriers to implement, which reduced its quality. Six sigma is a management tool that may be used to improve the quality of documentation information system. This study aimed to assess the documentation information system for primary health care accreditation using six sigma method.

Subjects and Method: This was a qualitative study conducted at Bekasi District Health Office, Bekasi, West Java, from July to August 2019. A sample of 7 informants was selected for this study by purposive sampling, including 1 manager of the quality of health service and accreditation, 3 accreditation companions, 3 representatives from accreditation working group. The data were obtained from in-depth interview and document review. The data were analyzed using six sigma method with 5 stages namely DMAIC (define, measure, analyze, improve, control),

Results: The six sigma included: (1) Define- clarified objective and test the benefit of each process, determine the resources needed, and the impact they cause; (2) Measure-measuring the performance by explaining it through process metric; (3) Analyze- analyze the main causes in the process by using cause and effect diagram; (4) Improve- proposed improvement to overcome the problem. This study was carried out only at the improve stage. Man, Money, Method, and Material were associated with the quality of documentation information system in primary health.

Conclusion: The method of documentation is significant factor that associated with the quality of documentation information system.
\end{abstract}

Keywords: six sigma, documentation, information system, accreditation, primary health care

\section{Correspondence:}

Dia Melisa Rafdi. Masters Program in Public Health, Faculty of Public Health, Universitas Indonesia, Depok, West Java. Email: diarafdi46@gmail.com. Mobile: 085263442946.

\section{BACKGROUND}

Accreditation of Community Health Center and other Primary Care Facilities (FKTP) is an effort to improve the quality and performance of services carried out through building a quality management system, organizing Health Efforts, and a clinical service system (Ministry of Health, 2015). A vital element of the FKTP accreditation success is documentation system.

The documentation system is important because it provides evidence of the implementation and application of policies, programs, and activities
A good documentation system allows personnel and organization to perform optimally (Ministry of Health, 2015).

Based on a preliminary study conducted by the author conducted in Bekasi district in March 2019, out of 39 accredited Community Health Center, 24 Community Health Center received only basic accreditation status, which is the lowest strata in accreditation status. The reason for the low achievement of the accreditation status is largely due to the problem of Documentation and Accreditation Records. 
Six Sigma is a quality management system oriented to customer satisfaction with a measurement of the target Sigma Quality Level. The analytical framework used in this analysis is known as DMAIC, which is define, measure, analyze, improve, and control. The five stages are carried out as an effort of improving a performance. This method has the aim to always reduce variation to near the perfect direction (zero defect) (Gaspersz, 2011). In other words, the level of quality obtained will be better.

Based on the above background, the authors feel the need to analyze the process of document control and recording of Community Health Center accreditation by using the Six Sigma method to find out the root of the problem and alternative remedial solutions as an effort to improve the quality and performance of the process of controlling Community Health Center documents and accreditation records, so that later the achievement of the results of Community Health Center accreditation in Bekasi district for the better.

\section{SUBJECTS AND METHOD}

\section{Study Design}

This research is a descriptive study with a qualitative approach through interview techniques and document analysis and this procedure was conducted at the Bekasi District Health Office in July-August 2019.

\section{Population and Sample}

Research respondents consisted of 7 people taken by purposive sampling technique, research respondents consisted of 1 person from the manager of the quality of health service and accreditation section, 3 accreditation assistant teams, and 3 representatives from each accreditation working group in one Community Health Center.

\section{Data Analysis}

The data collected was analyzed by the Six Sigma method through the DMAI approach (define, measure, analyse, improve) illustrated in Figure 1.

\section{RESULTS}

To find out information about the technical implementation process, such as document forms, data storage techniques and report preparation techniques, interviews were conducted with 3 representatives of each Community Health Center accreditation working group. To find out the flow of the document control process, interviews were conducted with representatives of the management section of the quality of health services and the Health Office accreditation.

While for the document evaluation process according to the needs of the accreditation, interviews were conducted with 3 representatives of the Bekasi District Health Center Accreditation companion team. To analyze the current system, Six Sigma method is used to develop the effectiveness and efficiency of the process.

In this study the Six Sigma analysis conducted refers to 4 approaches. Figure 1. define in this phase the first thing to do is to know the SIPOC process model (Supplier, Input, Process, Output, Customer) which is applied in the process of controlling Community Health Center accreditation documents. So that in the process of defining it has an appropriate and accurate foundation.

Next is identifying the problems of consumer complaints by conducting interviews with 7 samples. The consumers of the process of document control and records of Community Health Center accreditation are all Community Health Center employees, the health department, Accreditation advisory teams and Surveyors (Table 1). 


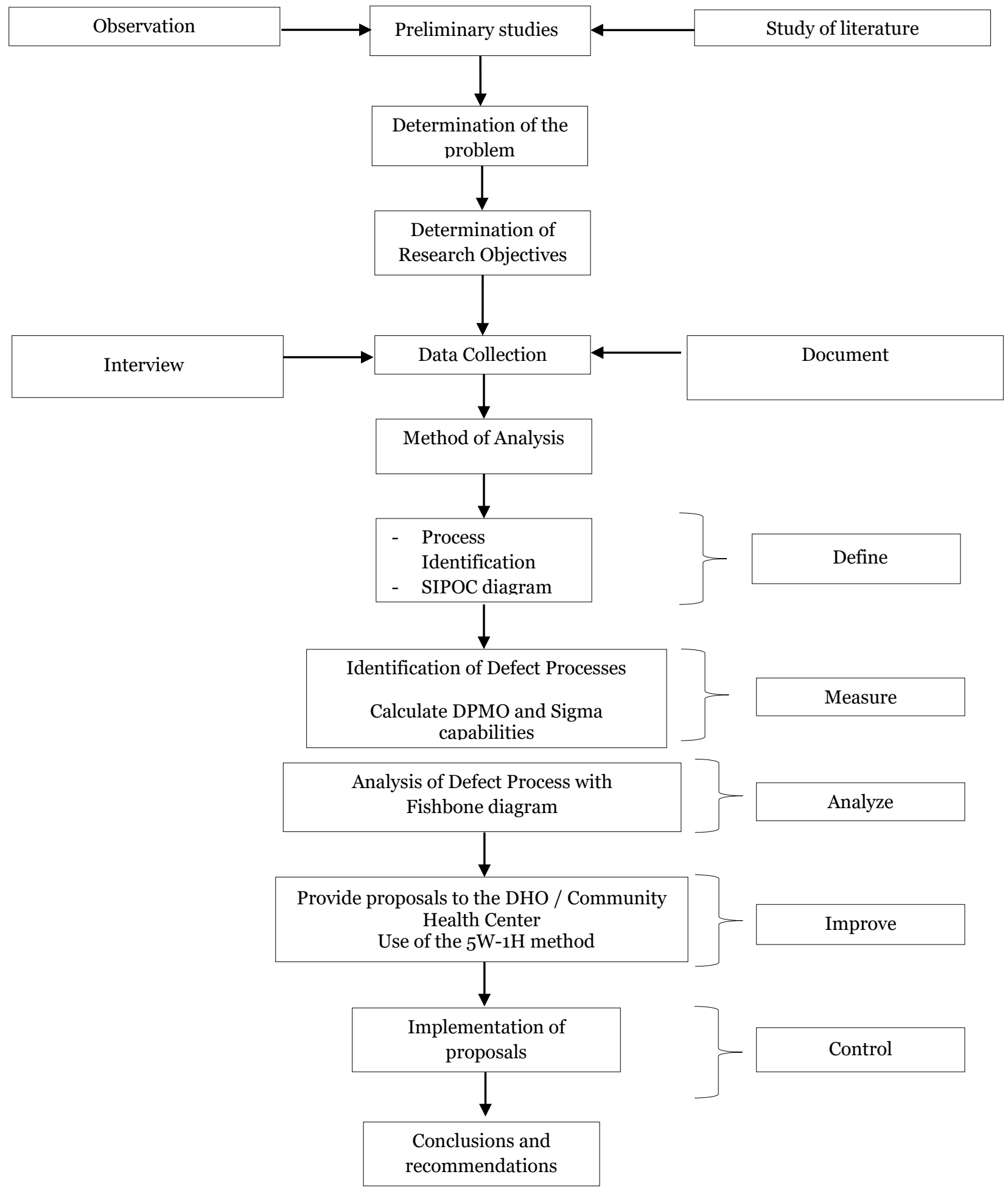

Figure 1. Chart of study method

The $6^{\text {th }}$ International Conference on Public Health 
Table 1. SIPOC document control process and records of community health center accreditation

\begin{tabular}{|c|c|c|c|c|}
\hline Supplier & Input & Process & Output & Customer \\
\hline $\begin{array}{l}\text { Head of the } \\
\text { Community } \\
\text { Health Center } \\
\text { Public health } \\
\text { Office } \\
\text { Regional } \\
\text { government } \\
\text { Ministry of } \\
\text { Health }\end{array}$ & $\begin{array}{l}\text { Computer / } \\
\text { laptop } \\
\text { Paper } \\
\text { A printer } \\
\text { Stationary } \\
\text { Human } \\
\text { Resources } \\
\text { Administration } \\
\text { Signature } \\
\text { Guidance Book } \\
\text { Making FKTP } \\
\text { Accreditation } \\
\text { Documents }\end{array}$ & $\begin{array}{ll}\text { 1. } & \begin{array}{l}\text { Identification of } \\
\text { Compilation / }\end{array} \\
\text { Amendment of } \\
\text { Documents } \\
\text { 2. }\end{array}$ & $\begin{array}{l}\text { Policy of Head of } \\
\text { Health Center, } \\
\text { Community Health } \\
\text { Center Five-Year } \\
\text { Plan, } \\
\text { Guidelines } \\
\text { / technical guidelines } \\
\text { related to } \\
\text { management } \\
\text { Standard operational } \\
\text { procedure (SOP) } \\
\text { Community Health } \\
\text { Center Level Planning } \\
\text { (PTP): Proposed } \\
\text { Activity Plan (RUK), } \\
\text { and Activity } \\
\text { Implementation Plan } \\
\text { (RPK) } \\
\text { Terms of Reference of } \\
\text { Activities. } \\
\text { Implementation } \\
\text { Record }\end{array}$ & $\begin{array}{l}\text { All units in } \\
\text { the Commu- } \\
\text { nity Health } \\
\text { Center } \\
\text { Accreditation } \\
\text { Assistance } \\
\text { Team } \\
\text { Surveyor }\end{array}$ \\
\hline
\end{tabular}

Table 2. Table of consumer complaints

\begin{tabular}{ll}
\hline Type of Complain & Total \\
\hline The process of preparing documents takes a long time & 5 \\
Inability in the process of searching documents & 2 \\
Document lost, scattered, torn & 2 \\
Dependency on the document-making officer & 3 \\
Spent a lot of paper & 2 \\
There is no document uniformity & 3 \\
Double document & 3 \\
Storage limitations & 2 \\
Too many documents prepared & 2 \\
Total & 24 \\
\hline
\end{tabular}

Of the 9 types of complaints above, it is grouped into 3 major groups namely, Complaints in the process of compiling docu- ments, complaints on distribution and storage and complaints in the search / retrieval process.

Table 3. Table Types of Consumer Complaints

\begin{tabular}{ll}
\hline Type of Complaint & Total \\
\hline Complaints related to the process of preparing the Document & 20 \\
Complaints related to the distribution and storage process & 2 \\
Complaints related to the process of searching and searching back & 2 \\
Total & 24 \\
\hline
\end{tabular}

\section{Measure}

Measure is a logical follow-up to the Define step and is a bridge to the next step. At this stage the measurement is done by calculating the capability of the process and converting DPMO to sigma values based on 
Motorola's 6-Sigma Process based on the Critical to Quality (CTQ) obtained. From the measurement results show that the highest order of complaints is complaints related to the document preparation process.

Table 5. Calculating the sigma capabilities of the Accreditation Document Preparation Process

\begin{tabular}{llll}
\hline Step & Activity & Equation & Results \\
\hline Step 1 & $\begin{array}{l}\text { What process do you want to know } \\
\text { about quality? }\end{array}$ & - & $\begin{array}{l}\text { Document } \\
\text { Preparation Process }\end{array}$ \\
Step 2 & $\begin{array}{l}\text { How many customers are served } \\
\text { Step 3 }\end{array}$ & $\begin{array}{l}\text { How many complaints / claims for } \\
\text { improvement from customers received }\end{array}$ & 24 \\
Step 4 & $\begin{array}{l}\text { Calculate the level of complaints based } \\
\text { on step 3! }\end{array}$ & $=$ (step 3)/(step 2) & 0,833 \\
Step 5 & $\begin{array}{l}\text { Determine the amount of potential } \\
\text { CTQ that can result complaints or } \\
\text { failures }\end{array}$ & $=$ many characteristics & 3 \\
Step 6 & $\begin{array}{l}\text { Calculate a brief Opportunity for } \\
\text { complaints per CTQ characteristic! }\end{array}$ & $=($ step 4)/(step 5) & 0,277 \\
Step 7 & $\begin{array}{l}\text { Calculate possible complaints per one } \\
\text { million chance (DPMO) }\end{array}$ & $=($ step 6) x 1.000.000 & 277.777 \\
Step 8 & $\begin{array}{l}\text { Convert DPMO (step 7) into sigma } \\
\text { value }\end{array}$ & $\begin{array}{l}\text { Conclusion } \\
\text { Step 9 }\end{array}$ & Sigma capability 2.09 \\
\hline
\end{tabular}

\section{Analysis}

In the analyze phase, analysis of the main factors that cause complaints in the document preparation process is done using a causal diagram. To make a cause-and-effect diagram, interviews were conducted with the management of the Community Health Center accreditation working group and the Community Health Center Accreditation Assistance Team to obtain information about the things that cause the main problems encountered in the document preparation process and were set out in the Fishbone diagram.

\section{Improve}

The fourth stage is Improve, this stage is to propose improvements (improve) by discussing ideas in improving the service work system based on the results of previous analysis, the priority in this improvement is the document preparation process. Improvements or innovations must be in accordance with the vision and mission of the Community Health Center, according to the
Voice of Customers, also must be realistic. Sources of root causes are identified and analyzed using the $5 \mathrm{~W}+1 \mathrm{H}$ technique.

a. Why?

This question asks about the importance of fixing the problem. Improvements must be made because the process of compiling documents cannot meet the expectations or desires of consumers. Continual improvement is made to achieve the 6-sigma capability.

b. What?

What is the purpose of the improvement? Improvements were made to improve the quality of the Community Health Center Accreditation Document Preparation Process, in accordance with customer expectations/ satisfaction. So that the outcome in the form of increased achievement of Community Health Center accreditation results in Bekasi District can be improved. 


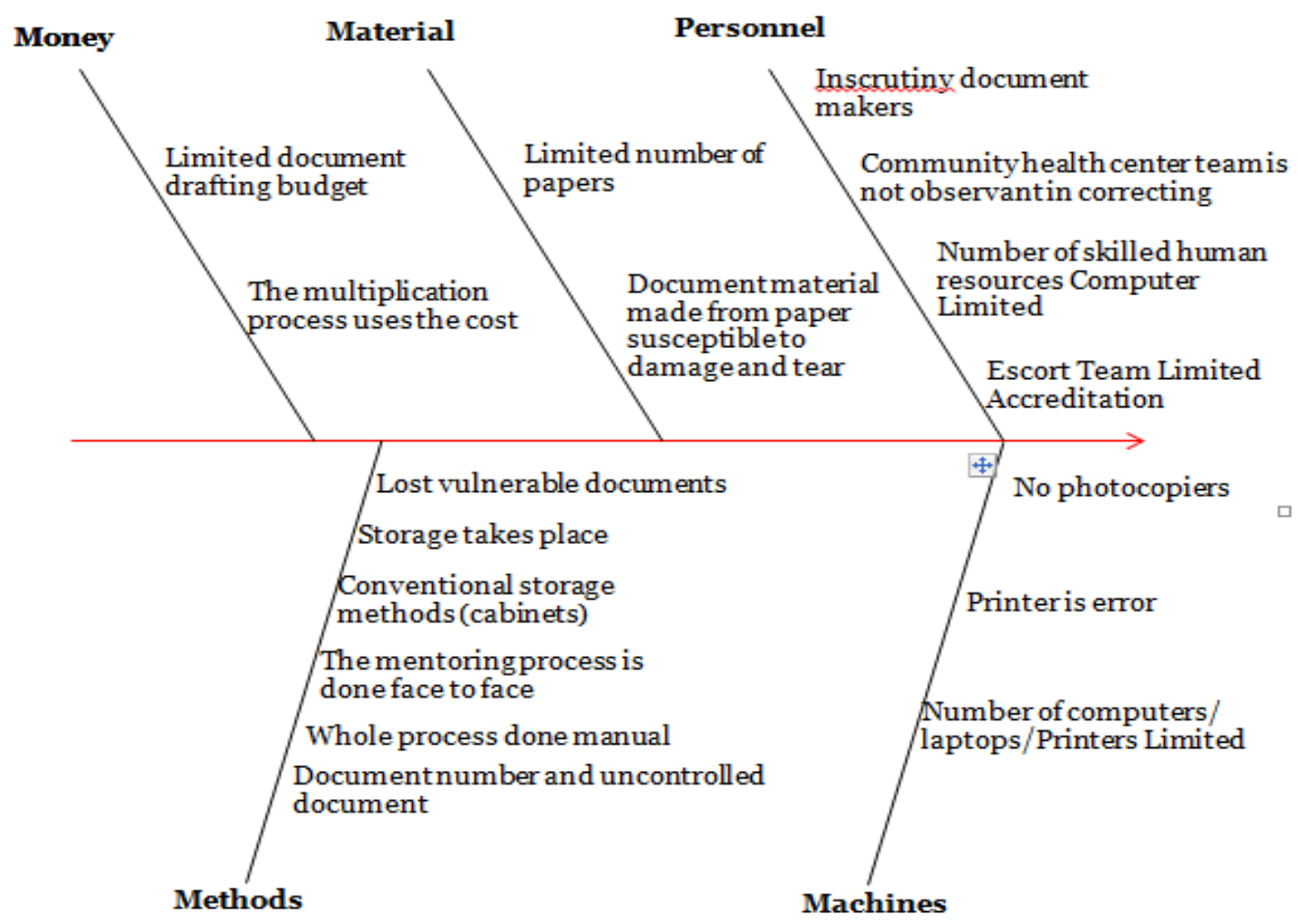

Figure 2. Fishbone diagram

\section{c. Where?}

Where is the improvement plan carried out? The improvement plan is implemented in 3 Community Health Center in Kabupaten Bekasi.

\section{d. When?}

When will repairs be made? Improvements are carried out every period and continuously, it is hoped that employees will be more skilled in performing services.

\section{e. Who?}

Who will work on the planned improvement activities? The improvement plan is carried out by the management of the Community Health Center and the Health Office by involving all employees and carried out together.

\section{f. How?}

This question is about how to fix it.
Corrective actions that need to be taken by the Community Health Center and Bekasi District Health Office for the problems in preparing the Documents are as follows:

a. Making guidance for document control and accreditation records of the scope of the Bekasi District health office to be applied at the health office and community health center

b. Enhance the skills of Human Resources (HR) about the process of controlling documents and records

c. Checking, repairing and updating administration tools such as computers and printers

d. Update the method by utilizing information technology. Creating an FKTP Accreditation Document and Records Information System that is able to accommodate, store and retrieve all documents related to accreditation evidence in accordance with the standards 
and elements of the accreditation assessment, which can be accessed by Community Health Center, health offices, companion teams and surveyors, so that it will have an impact on improving cost efficiency, data integration, accessibility and ease in monitoring the implementation of accreditation as well as guarantees of data availability.

\section{DISCUSSION}

The Six Sigma concept was first applied by Motorola in 1980 (Gasperz, 2002). SixSigma is a structured methodology for improving processes that are focused on efforts to reduce process variations while reducing defects by using statistics and problem solving tools intensively (Pande, 2002).

Sugiharto (2004) argues that six sigma is needed by every company because it contains elements of understanding, measurement and continuous improvement of the activity process for the sake of customer satisfaction so that the occurrence of storage can be minimally suppressed. As a methodology for solving problems or improving processes, six sigma strategies have a series of steps or stages that are formulated as DMAIC (Gaspersz, 2007). According to Evans and Lindsay (2007), DMAIC stands for Define, Measure, Analyze, Improve, and Control.

Based on the results of the analysis using the Six Sigma method to determine the quality of the document control process and Community Health Center accreditation record within the scope of the Bekasi District Health Office, it can be concluded that:

At the Define stage, it is known that people involved in the process of document control and Community Health Center accreditation records are depicted in the SIPOC diagram (Table 1), so to make improvements to the quality of document control and accreditation records must involve them, both from the supplier side and from the customer side. In this study, 7 people taken were those who were directly involved in the document control process and the Community Health Center accreditation record in the Bekasi district.

From them as customers obtained complaints that become obstacles in the process of controlling the health center accreditation documents. There are 9 types of complaints submitted by customers which are then grouped into 3 types namely Complaints related to the process of compiling Documents, Complaints related to the process of distribution and storage, Complaints related to the process of searching and retrieval.

Of the three Voice of customers, the Complaints related to the process of compiling the Documents were the most complaints submitted, and this process was determined as CTQ (Critical to Quality).

The document preparation process here means that the document control process starts from stage 1 to stage 5 of 9 the document control process and the Community Health Center accreditation record (Table 1).

The process of preparing and implementing documents is the fourth and fifth stage in the process of Accreditation of Community Health Center after the Commitment Supporting Workshop, Workshop on Understanding Standards and Accreditation Instruments and Self-Assessment ( $\mathrm{MOH}, 2019)$. This process is the most time and energy consuming process compared to other processes in implementing Community Health Center accreditation. It takes 4 to 5 months from 9 months to prepare for Community Health Center accreditation.

After CTQ was found, then the level of performance measured by the performance results used in Six Sigma was measured, 
the level of Defect Per million Opportunity (DPMO). The measurement is carried out to determine the current state of the process which will be an illustration of the corrective steps that must be carried out. from the measurement of the performance of the accreditation document preparation process, the DPMO value of 277,777 was subsequently converted into a six sigma value and a sigma score of 2.09 which means that the sigma value obtained was still low and still far from 6 sigma. This illustrates that the performance of the document control process and the accreditation record are still not good. So it is necessary to improve quality.

Then the analysis phase is carried out. In this phase, an analysis of the main causes causing problems in the process of preparing documents using fishbone diagram depicted in Figure 1. After brainstorming and deep interviews with 7 informants, the method was determined as the core problem in the process of preparing accreditation documents. So for the Improve stage, the proposed improvement proposals given are solutions related to the method.

Improve Phase is the stage of determining the action plan (action plan) to carry out the improvement of the quality of Six Sigma. The proposed improvement plan is the Making of Document Control Guidelines and Accreditation records and Method renewals by utilizing Information Technology and making FKTP Accreditation Document and Records Information Systems.

Because of the limited time of the study, the control stage cannot be done by the researcher. The control phase is the process of implementing the action plan. Researchers or other researchers can continue to the control stage so that improve- ments in the quality of document control and Community Health Center accreditation records can be realized so that the achievement of Community Health Center accreditation results is better.

\section{REFERENCES}

Nakhai B, Neves JS (2009). The challenges of six sigma in improving service quality. Int J Qual Reliab Manag, 26(7): 663-684

Goetsch DL, Davis S (2014). Quality management for organizational excellence: Introduction to Total Quality.

Franchetti MJ. (2015). Lean six sigma for engineer and managers. New York: Taylor and Francis Group

Fursule NV, Bansod SV, Fursule SN (2012). Understanding the benefits and limitations of six sigma methodology. Int J Sci Res Pub, 2(1): 1-9. Retrieved from http://www.ijsrp.org/research_paper_jan2012/ijsrp-jan-2012-32.pdf

Gaspersz, Vincent (2011). Lean six sigma for manufacturing and service industries. Vinchristo Publication: Bogor.

Parast MM (2011). The effect of six sigma projects on innovation and firm performance, Int J Proj Manag

Pande P, Larry H (2002). What is six sigma? New York: McGraw-Hill

Sknapp S (2015). Lean six sigma implementation and organizational culture, Int J Health Care Qual. Assur

Syukron A, Kholil M. (2012). Six sigma quality for business improvement. Graha Ilmu: Jakarta

Thakore $\mathrm{R}$ (2014). A review: six sigma implementation practice in manufacturing industries. Int J Engineer Res Applications. 4(11). 